\title{
The horse racing industry and the efficient markets hypothesis
}

\author{
J.F. Affleck-Graves, A.H.Money* and K.Miedema \\ Graduate School of Business, University of Cape Town, Private Bag, Rondebosch 7700, Republic of South Africa
}

\author{
Received February 1986; accepted October 1986
}

\begin{abstract}
Betting on the racetrack and investing in the stockmarket have many characteristics in common. These similarities are discussed in this paper and the applicability of efficient markets theory to the market for horse racing bets in South Africa is examined. Both the weak form and the strong form of the efficient market hypothesis are empirically tested. The results indicate support for both forms although some small deviations from the theory do exist. Most notable of these is that on average long-odds horses win lessfrequently than suggested by their quoted odds whilst short-odds horses win more frequently than implied by their odds. However, these weak form deviations are not sufficient to enable consistent profits to be made. The performances of ten experts with potential access to inside information are examined and the results indicate that on average they are not able to earn superior investment retums. In facl, all ten had negative retums over the period examined andonly three of them did better than the naive strategy of backing the favourite.
\end{abstract}

Investering in die aandelemark en wed by die renbaan het baie in gemeen. Hierdie ooreenkomste word bespreek in hierdie artikel asook die toepasbaarheid van doelmatige markteorie tot die mark vir renbaanwedrenne in Suid-Afrika. Beide die swak en sterk vorme van doelmatige markhipoteses word empiries getoets. Die resultate ondersteun beide vorme alhoewel klein afwykinge vanaf die teorie tog voorkom. Mees opvallend was dat 'iong-odds'-perde minder gereeld wen as wat deur die gekwoteerde kansfaktor ge'impliseer word, terwyl 'short-odds'-perde meergereeld wen aswat deurgekwoteerdekansfaktorge impliseerword. Dog, hierdie afwyking van die swak vorme is nie genoegsaam om gereelde wins te verseker nie. Die gedrag van tien kenners met potensiẻle toegang tot inligting uit die binnekringe word ondersoek en die bevindinge toon dathulle nie in staat is om superieure investerings te maak nie. Inderdaad, al tien het negatiewe resultate oor die periode van ondersoek getoon en slegs drie het beter gevaar as die na'iewe strategie van kans op die gunsteling te plaas.

*To whom correspondence should be addressed

\section{Introduction}

Financial and investment analysts throughout the world invariably show great interest and aptitude in analysing the stock market. The promise of a handsome return based on what is considered to be judgment, sometimes with the assistance of sophisticated models, is regarded as very attractive. However when the probability of sound investment with very acceptable returns through the medium of thoroughbred racing is mooted in the same circles, severe reservations are expressed. This is generally due to a lack of understanding of the principles of thoroughbred racing, coupled with the stigma often attached to all forms of gambling.

Despite the social stigma, many efforts have been made over the past 50 years to develop betting systems which would ensure the investor considerable return on his investment. Indeed, the popularity of betting and horse racing bears testimony to the fact that many believe that the horse racing industry does provide a lucrative investment medium.

Recently however, as with stock market investments, questions have been raised as to whether investors in the horse racing industry can really expect to earn superior returns on the basis of fundamental or technical trading strategies. Most of these studies have concentrated on the efficient market hypothesis (EMH) and have been confined to the United States.

In this paper, the South African racetrack betting industry will be examined in terms of the efficient market hypothesis. In the next section the relevance of the EMH in the horse racing industry is discussed. In addition some similarities between the betting market and the stock market are discussed. In Section 3, two tests of weak form efficiency are presented and the results contrasted with similar tests performed in the United States. Section 4 focuses on the strong form of the EMH by examining the performance of ten professional tipsters. Finally some conclusions are presented in Section 5.

\section{The efficient market hypothesls and horse racing} The concept of an 'efficient market' refers to a perfectly competitive market in which prices reflect all available information (Snyder, 1978:1109). In the context of security markets this implies that no method can be found which will consistently detect securities which are undervalued by the market. This is an extremely strong assertion and is unlikely to be universally true in any real world market. Aocordingly, financial theory has evolved three different levels of efficiency, weak, semi-strong, and strong form efficiency (Fama,1970). Briefly, weak form efficiency asserts that knowledge of past share prices cannot be used to predict future price changes. Semistrong efficiency asserts that use of any publicly available information will not result in superior forecasts of future price changes. Finally, strong form efficiency asserts that even non-publicly available (i.e.insider) information will not result in superior forecasts of future price changes.

The question which arises is whether or not security markets and the horse racing betting market are comparable to the extent that the theory of efficient markets is applicable to horse racing as well. These two markets are similar to the extent that both have large numbers of 
participants with extensive market knowledge and ease of entry and both involve economic decision-making under conditions of risk and uncertainty. In the light of this it would appear that the model could effectivelybe applied to horse racing. Attempts to do this have appeared in the finance literature and some of these are briefly reviewed here.

Investigations of the efficiency, or lack of it, of the horse racing betting market have, so far, been restricted to the USA and have not been entirely successful. Snyder (1978) reviewed five major studies (Fabricant, 1965; Griffiths, 1949: McGlothlin, 1956; Seligmann, 1975; Weitzman, 196.5) on weak form efficiency and concluded that there was no reason to believe that the market was not efficient. In addition, Snyder examined the semi-strong and strong forms of the EMH and concluded that insufficient data were available to demonstrate absence of an efficient market. Snyder was taken to task on this by Vannebo (1980), who specifically disagreed with Snyder's definitions of weak and strong form tests. Vannebo proposed what was in his view a proper test of the efficient market hypothesis, but did not provide any empirical results. Much earlier, Seligmann (1975) had concluded that the horse racing betting market was rather inefficient; however, his definition of what constitutes an efficient market appears to be rather broad.

In the light of these inconclusive findings a new attempt is made to re-define Fama's three subsets in horse racing terms. In addition the basic information used is somewhat different; all the above studies make use of totalisator odds, whereas this study uses bookmaker's odds, quoted in the form of starting prices. These starting prices are preferred not only because 'smart money' tends to originate with bookmakers, while the tote follows, but primarily because tote odds are publicly available only for winners, and not for all runners. The subsets have therefore been adapted to South African circumstances, but the major difference to earlier studies lies in the definitions.

In stock mark et investigations of the EMH, the data are provided in the form of the market price. This is assumed to reflect the average expectation of the future price of all investors in the market. The key issue is whether any individual investor can consistently determine a more accurate estimate of the future price than that reflected in this market price. In horse racing the analogy to the market price is the quoted odds of the horse. That is, the bookmakers (and the totalisator board) quote odds which should reflect an average assessment of the horses winning that particular race. The key issue therefore revolves around whether or not a particular individual can consistently obtain better estimates of the probability that a horse will win a particular race. If he can, then clearly he will have the opportunity of earning abnormal returns by placing his money on those horses which have a greater chance of winning than is reflected in their quoted odds.

The weak form of the EMH in the horse racing context would thus state that the odds quoted on a horse at the start of a race provide the best available estimate of the probability that that horse will win. This hypothesis is tested in Section 3.
The semi strong form of the EMH would imply that all publicly available information, such as the jockey, the weight, the weather, the going, the draw, etc., cannot be used to obtain superior estimates of the probability of the horse's winning. To test this form of the EMH would be extremely difficult as every possible item of publicly available information would have to be considered. Accordingly this form will not be tested in this paper.

The strong form of the EMH implies that even inside information (i.e. information that is not publicly available) cannot be used to obtain superior estimates of the horse's winning. As such, it is clear that the strong form test concerns itself with monopolistic access to information. The fact that successful betting coups do exist is ample evidence that monopolistic access is not a fallacy in horse racing terms. However, this access relates to isolated cases, by different groups of people, and is not likely to produce any long-term profits for any one group. In addition bets by groups or syndicates are not consistently reported. For example, when Rain Forest won the Richelieu Guineas at Milnerton in February 1983, his connections reputedly cleared over one million rand from bets placed across the country; the long-term effect of this one bet is certainly significant but relates to the profit objectives set by a group who won their bet. For the purpose of this study, however, consistent long term profits are necessary to demonstrate non-compliance with the strong form of the EMH. How much money, for instance, did the Rain Forest group lose on his subsequent defeats? These facts are obviously not advertised as proudly as the winnings.

There are, however, two groups of people whose profession it is to produce better than average results, and who should, in theory at least, possess a network information system providing above average information. The first group are the bookmakers, who operate in a highly competitive environment and whose survival depends on the making of a regular profit on turnover. It must be realized, however, that making a book is largely a matter of mathematics, and that information-gathering plays no more than a marginal role.

The second group is perhaps the best toillustrate market efficiency in terms of the strong form. This group consists of the so-called experts: newspaper tipsters and professional tipsters. It is this latter group which is used to test the strong form of the EMH in Section 4.

Finally, it should be noted that the three forms of the EMH are not independent. Acceptance of the strong form automatically implies acceptance of the weak and the semi-strong form. Similarly, acceptance of the semi-strong form implies acceptance of the weak form. However the reverse does not apply. Thus acceptance of the weak form does not per se imply acceptance of either the semi-strong or the strong form. And, acceptance of the semi-strong form does not imply acceptance of the strong form.

\section{Testing weak form efficlency}

In order to test the weak form of the EMH it is necessary to compare the subjective probability of the horse's winning a race as implied in the bookmakers' odds with the actual probability that the horse will win. Unfortunately, the 
latter probability is never known - any horse in any race either wins or does not win. However, by studying several races one can ascertain whether horses in particular odds groups do indeed win as often as implied in the bookmakers' odds. This would then provide a test of the weak form of the EMH.

Therefore, the starting odds of all horses which ran in the Western Cape between November 20, 1982 and August 28, 1983 were collected together with races in other centres for which the Cape bookmakers offered odds. This gave a total of 6781 runners in 621 races. These starting prices were then combined into ten odds groups chosen to provide a reasonable subdivision.

These odds were converted to subjective probabilities of winning as follows:

$$
P_{h}=1 /\left(1+O_{h}\right)
$$

where $P_{h}=$ the subjective probability that the horse wins; and $O_{h}=$ the odds quoted by the bookmaker.

Thus for example, a horse quoted at 3:1 was assumed to have a subjective probability of $1 / 4$ of winning the race.

For each of the odds groups, the overall subjective probability was calculated as the average of the subjective probabilities of all horses starting races in that odds group. That is

$$
S P_{G}=\sum_{i=1}^{n_{G}} P_{h} / n_{G}
$$

where $P_{G}=$ the average subjective probability for odds group $G ; n_{G}=$ the number of horses in the sample in odds group $G$; and $P_{h}$ is as previously defined.

The actual proportion of winners in each odds group was then calculated as

$$
A P_{G}=N_{G} / n_{G}
$$

where $A P_{G}=$ the actual proportion of winners in odds group $G ; N_{G}=$ the actual number of winning horses in odds group $G$; and $n_{G}$ is as previously defined.

The results are summarized in Table 1. These results show that, in general, the betting odds do provide a very good estimate of the probability of the horse's winning the race. This concurs with results from US thoroughbred races (Ali, 1977), Asch, Malkiel, \& Quandt, 1982).

Table 1 also presents results of a test of whether or not the subjective probability and the actual proportion are significantly different. This was done by assuming that the actual proportion was the true probability and assuming a binomial process. Thus, the test statistic $Z$ was calculated for each odds group as

$$
Z_{G}=\left(S P_{G}-A G_{G}\right) /\left(A P_{G}\left(1-A P_{G}\right) / n_{G}\right)^{1 / 2}
$$

Note that while the bookmakers odds do provide a good estimate of the true probability of a horse winning, there is a clear tendency (as was found by Ali (1977) and Asch et al. (1982)) for favourites to win more often than expected. Conversely, there is a tendency for the long odds horses to win less frequently than suggested by the odds. This is discussed further in Section 5.

An alternative test of weak form efficiency is to examine whether knowledge of the subjective probabilities as reflected in the bookmakers odds can be used to earn above average returns.

If the market is efficient, then the expected rate of return for all types of bets would be identical. In fact, it should be negative and equal to the bookmakers 'take'. On the other hand, if the market is not efficient and investors systematically assign subjective odds different to the actual probabilities of winning, then the rates of return will not be identical over all odds groups.

To examine this further, the 621 races examined earlier were re-evaluated on the assumption that all starters in the race had been backed at a level stake of $R 1$. The actual rate of return for each odds group can then be calculated as

$$
R R_{G}=\left(1+(1-t) W_{G}-N\right) / N
$$

where $\boldsymbol{R} \boldsymbol{R}_{G}=$ the rate of return earned by an investor betting on all horses in odds group $G ; t=$ the percentage deducted by the bookmaker for tax (taken as $10 \%$ ); $W_{G}=$ the average starting odds of all winning horses in odds group $G$; and $N=$ the total number of horses sampled.

Note that the above formula pertains because bookmakers deduct $10 \%$ from winnings only, with the original stake refunded in full.

In addition tocalculating the actual rate of return earned in each odds group, the expected rate of return $\left(E R_{G}\right)$ can be calculated by replacing the average starting odds of all winning horses in odds group $G$ by the average starting odds of all horses sampled in odds group $G$. Mathematically this yields

$$
E R_{G}=\left(1+(1-t) A_{G}-N\right) / N
$$

where $A_{G}=$ the average starting odds of all horses backed in odds group $G$; and all other symbols are as previously defined.

Table 1 Subjective and actual probabilities of winning

\begin{tabular}{lrccc}
\hline & $\begin{array}{c}\text { Number } \\
\text { in group }\end{array}$ & $\begin{array}{c}\text { Subjective } \\
\text { probability }\end{array}$ & $\begin{array}{c}\text { Actual } \\
\text { proportion }\end{array}$ & $Z_{0}$ \\
\hline Up to $5 / 10$ & 22 & 0,79 & 0,81 & $-0,24$ \\
$5 / 10$ to $9 / 10$ & 105 & 0,57 & 0,52 & $+1,03$ \\
Ev. to $14 / 10$ & 130 & 0,46 & 0,37 & $+2,13 *$ \\
$15 / 10$ to $18 / 10$ & 152 & 0,37 & 0,35 & $+0,52$ \\
$2 / 1$ to $28 / 10$ & 361 & 0,30 & 0,27 & $+1,28$ \\
$3 / 1$ to $7 / 2$ & 308 & 0,23 & 0,21 & $+0,86$ \\
$4 / 1$ to $9 / 2$ & 377 & 0,19 & 0,16 & $+1,59$ \\
$5 / 1$ & 376 & 0,17 & 0,14 & $+1,68$ \\
$6 / 1$ to $10 / 1$ & 1633 & 0,11 & 0,07 & $+6,34 *$ \\
$12 / 1$ upwards & 3317 & 0,03 & 0,01 & $+11,5 *$ \\
\hline
\end{tabular}

*Indicates significant at 5\% level 
The results obtained from the sample period are presented in Table 2. From the results it is clear that the actual rate of return is not identical across all odds groups, but declines fairly steadily from the odds on groups to the long odds groups. This is partly due to the payment system which results in taxes being deducted from winnings but not from the stake. Therefore, as can be seen in Table2, the rate of return is expected to decline from the top odds on group to the bottom long odds group. However, the extent of the decline in the actual return is clearly unexpected under the null hypothesis of weak form market efficiency. These results are not dissimilar to those obtained from the US horse racing industry (for example, Snyder, 1978 and Ali, 1979).

Taken together, the results presented in this section indicate that the South African horse racing betting market might exhibit some divergence from weak form efficiency. Firstly, the odds quoted by bookmakers do not appear to fully reflect the probability that a horse will win a given race. Secondly, the return which can be earned by betting on all horses in a given odds groups is not constant across the ten odds groups examined. Both of these indicate non-compliance with weak form efficiency. However, it should be noted that the divergence which exists may not be as marked as at first appears. The actual return which can be earned by betting on all horses in any one odds group is negative for all groups other than the first group which comprised very short odds horses. Even in this case the return which could be earned was only $1 \%$. Thus the observed divergence from perfect weak form efficiency may be nothing more than a reflection of the bookmakers take. From a practical point of view, it could still be argued that weak form efficiency holds, as the earning of abnormal profits from knowledge of the quoted odds does not appear possible. Indeed, inefficiency could only be concluded if it could be shown that unexpected arbitrage opportunities were being consistently neglected (Asch, Malkiel, \& Quandt, 1984:166). Also the fact that a bias appears to exist in the odds relative to the probabilities of winning does not imply market inefficiency. It might merely imply a preference for a positively skewed distribution of rates of return (Vannebo, 1980:201).

Table 2 Actual and expected rates of return

\begin{tabular}{lcc}
$\begin{array}{l}\text { Odds group } \\
\text { of return }\end{array}$ & $\begin{array}{c}\text { Actual rate } \\
\text { of retum }(\%)\end{array}$ & $\begin{array}{c}\text { Expected rate } \\
(\%)\end{array}$ \\
\hline Up to $5 / 10$ & +1 & $-2,1$ \\
$5 / 10$ to $9 / 10$ & -14 & $-4,3$ \\
Ev. to $14 / 10$ & -24 & $-5,4$ \\
$15 / 10$ to $18 / 10$ & -11 & $-6,3$ \\
$2 / 1$ to $28 / 10$ & -29 & $-7,0$ \\
$3 / 1$ to $7 / 2$ & -18 & $-7,7$ \\
$4 / 1$ to $9 / 2$ & -24 & $-8,1$ \\
$5 / 1$ & -25 & $-8,3$ \\
$6 / 1$ to $10 / 1$ & -43 & $-8,9$ \\
$12 / 1$ upwards & -77 & $-9,7$ \\
\hline
\end{tabular}

Finally, it must be stressed that all tests were performed for winning bets only. No attempt was made to examine place bets or any other type of bets. This may be an important omission since one study in the United States (Hausch, Ziemba, and Rubinstein, 1981) has suggested that it is possible to make substantial positive profits using a technical system for place and show betting. Further research is necessary to determine whether similar inefficiencies exist in the South African betting industry.

\section{Tests of strong form efficiency}

In the context of strong form efficiency, the horse racing industry has many similarities with the stock market. In particular, as in the stock market, there are numerous knowledgeable 'insiders' who may be able to profit from their unique position. Many writers, for example Miedema(1983) and Snyder (1978) have discussed individuals such as owners, trainers, jockeys, grooms, stablehands, veterinary surgeons, etc., all of whom have some unique information about a given horse's chances in a particular race. However, to date, noonehas been capable of collecting the predictions of these 'insiders' and submitting them to a rigorous test of the strong form of the EMH. Indeed, the possibility of performing such an analysis in the near future appears highly unlikely.

However, in the case of horse racing, there is at least one major group of so-called 'experts' who regularly make public their prediction for a given race. These are the newspaper and professional tipsters. It can be argued that these members of the press have more time to devote to studying form, have access to and contact with many of the influential people mentioned above (i.e. owners, trainers, jockeys, etc.) and usually have many years of experience on which to base their judgments. Therefore, one might assume that these tipsters should be able to provide assessments of a horse's probability of winning a race which are superior to those implied in the bookmakers odds which reflect the average assessment of the public at large.

Therefore the strong form of the EMH was examined by selecting eight newspaper tipsters, four from the Cape Times and four from the Argus, and two professional tipsters. Their selections were monitored over the period November 30, 1982 to August 28, 1983. Each tipster's winning selection was recorded by odds category and their return on investment after tax calculated, at a level stake per race. The overall analysis is summarized in Table 3. The first column gives a letter representing the tipster, followed by the number of selections given during the period under consideration. This is followed by their number of winners, winning percentage (or strike rate), and after-tax rate of return.

An analysis of Table 3 clearly indicates that the tipsters examined do not appear able to consistently select winners. Indeed for each tipster a strategy of betting on each of their selections over the period examined would have resulted in a negative return on investment. Indeed the best return involved a substantial loss of $12 \%$. In addition none seemed to perform significantly better than the naive strategy of betting on the market favourite. Such a strategy resulted in a higher strike rate than that achieved 
Table 3 Evaluation of the strong form test for 10 experts winning selections

\begin{tabular}{ccccc} 
& \multicolumn{4}{c}{ All horses (20.11-28.8) } \\
Fxpert & Selected & Won & Strike Rate & Profit (\%) \\
\hline A & 584 & 151 & 0,258 & -34 \\
B & 519 & 147 & 0,283 & -24 \\
C & 593 & 136 & 0,229 & -22 \\
D & 505 & 150 & 0,297 & -18 \\
E & 421 & 131 & 0,311 & -12 \\
F & 533 & 131 & 0,246 & -13 \\
G & 586 & 156 & 0,266 & -29 \\
H & 573 & 154 & 0,269 & -30 \\
I & 590 & 166 & 0,281 & -19 \\
J & 522 & 157 & 0,337 & -15 \\
& & & & -18 \\
\hline Market favourite & 602 & 203 & 0,337 & \\
\hline
\end{tabular}

by any individual tipster (i.e. 0,337 ) although an overall Inss of $18 \%$ would have resulted from the use of this strategy. Nevertheless, this was still better than the return earned by 7 of the 10 tipsters examined.

In summary, therefore it appears that the strong form of the efficient market hypothesis is supported by the data and that above average profits cannot be made by following the advice of so-called experts. There are considerable differences between the experts, but none of them shows a long term profit, using all selections. More conclusive evidence of expertise could only be given if the experts were to state what, in their opinion, constituted a selection worth betting on. Unfortunately, such information is not published.

Finally, it should be noted that this test of the strong form of the EMH is dependent on the fact that the experts examined do possess inside information. If this were not so, the test would constitute a test of semi-strong efficiency rather than strong form efficiency (Losey \& Talbott, 1980:1040).

\section{Conclusions}

In this paper both the weak form and the strong form of the EMH have been examined using empirical data. The results clearly indicate that consistent positive profits cannot be expected from horse race betting, a conclusion similar to that reached for security markets worldwide. However, the market did reveal some divergence from perfect efficiency in that for lower odds horses (i.e. odds-on) the subjective probability of winning appears to significantly underestimate the empirical (actual) probability of winning. For higher odds horses the opposite prevails. It should be noted that similar results have been found in studies done on the US horse racing industry and therefore the results presented do not suggest any weakness on the part of South African bettors. Rather because they appear to be part of a worldwide phenomenon the results suggest that a sound reason for the difference may exict
No evidence was presented which would explain why the differential should exist between the low odds and high odds group. We can therefore only speculate that the differences exist either because of market inefficiency or because of differences in race track bettors' attitudes to risk; that is, the results suggest that bettors on average prefer the chance of a large win (even with very small probability of success) to that of a small win with very high probability. The difference that exists might therefore be a premium paid by investors for the thrill or excitement of a large payout from a small stake. Alternatively they may merely reflect a preference on the part of investors for positively skewed distributions of return.

The fact that investors' attitudes torisk might affect their betting strategy has received some attention in the literature. In particular, it has been shown that the tendency to overbet long odds horses is even stronger towards the end of the racing day (Asch, et al., 1982; McGlothlin, 1956). This would be consistent with a policy whereby bettors may be betting on horses with sufficiently long odds to give them the chance of breaking even.

The contribution that these studies make towards examining investment decisions under risk have implications beyond the horse racing industry itself. For example, in the area of capital markets research, many studies empirically examining the CAPM have concluded that, ex post, high risk shares appear to earn less return than expected, while low risk shares earn more return than expected (e.g. Fama \& MacBeth, 1973). Therefore the empirical security market line is flatter than would be expected under capital market theory. Reasons for this have usually been ascribed to methodological weaknesses in the empirical testing process. However, the results are remarkably consistent with those found in the horse racing industry. There appears therefore to be a general tendency in the security markets and the horse racing market for investors to overbet or overprice high risk or long odds investments and to underprice or underbet low risk or low odds investments. The explanation for this almost certainly lies in a better understanding of investors' behaviour under conditions of risk rather than in empirical methodological weaknesses. It is our contention that the horse racing industry provides a good forum for such an investigation and should be the focus of far more empirical research than it has historically received.

\section{References}

Ali, Mukhtar M. 1977. Probability and utility estimates for racetrack betting. J. Polit. Econ., vol.85,803-815.

Ali, Mukhtar M. 1979. Some evidence of the efficiency of a speculativemarket. Econometrica, vol.47,387-392.

Asch, P., Malkiel, B.G., \& Quandt, E. 1982. Racetrack betting and informed behaviour. J. Fin. Econ., vol.10,187-194.

Asch, P., Malkiel, B.G., \& Quandt, R.E. 1984. Market efficiency in racetrack betting. J. Bus., vol.57, 165- 195.

Fabricant, B.F. 1965. Horse sense. New York: David McKay.

Fama,E.F. 1970. Efficient capital markets: A review of theory and empirical work. J. Fin., vol.25, 383-417.

Fama,E.F. \& MacBeth, J. 1973. Risk return and equilibrhum: empirical tests. J. Polit. Econ., vol.81, 607-636. 
Griffith, R.M. 1949. Odds adjustments by Americanhorse race bettors. Am. J. Psychol., vol.62.290-294.

Hausch. D.B. .Ziemba, W.T. \& Rubinstein, M. 1981. Efficiency of the market for racetrack betting. Manage. Sci., vol.27, 1435-1452.

Losey, R.L. \& Talbott, J.C. 1980. Back on the track with the efficient markets hypothesis. J. Fin., vol.35, 1039- 1043.

McGlothlin. W.H. 1956. Stability of choices amonguncertain alternatives. Am. J. Psychol., vol.69,604-615.

Miedema, K. 1983. Horse racing: A scientific approach to investment through handicapping. UnpublishedMBA Tech. nical Report, Graduate School of Business, University of Cape Town.

Seligman, D. 1975. A thinkingman's guide to losing at the track. Fortune, vol.92,81-87.

Snyder,D. 1978. Horse racing: Testing the efficientmarkets model. J. Fin., vol.33, 1109-1118.

Vannebo, 0. 1980. Horse racing: Testing the efficientmarket: Comment. J. Fin., vol.35,201-202.

Weitzman, M. 1965. Utility analysis and group behaviour: An empiricalstudy. J. Polit. Econ., vol.73,18-26. 